\title{
Recent Reprints and Paperbacks
}

With this first issue in volume 49 , the Annals of Iowa reinstates the listing of recent reprints, which was instituted and explained in the Winter/Spring 1986 issue of the Annals. In this way we hope to call attention to the availability of these books without offering reviews, which would be superfluous in most cases.

The Frontier in American History, by Frederick Jackson Turner, with a foreword by Wilbur R. Jacobs. 1920. Reprint. Tucson: University of Arizona Press, 1986. xxii, $375 \mathrm{pp}$. Notes, index. $\$ 10.95$ paper. Contains the essay that first developed the influential "Turner thesis" and twelve other essays that "are commentaries in different periods on the central theme of the influence of the frontier in American history."

The Great Father: The United States Government and the American Indians, by Francis Paul Prucha. Abridged edition. Lincoln: University of Nebraska Press, 1984, 1986. xii, 426 pp. Maps, tables, appendixes, bibliography, index.

Jefferson and Southwestern Exploration: The Freeman \& Custis Accounts of the Red River Expedition of 1806, edited, with introduction and epilogue by Dan L. Flores. Norman: University of Oklahoma Press, 1984. xx, 386 pp. Notes, illustrations, maps, appendixes, bibliography, index. $\$ 14.95$ paper.

Landmarks of the West: A Guide to Historic Sites, by Kent Ruth. 1963. Revised edition. Lincoln: University of Nebraska Press, 1986. ix, 309 pp. Map, illustrations, index. $\$ 39.50$ cloth; $\$ 17.50$ paper. Contains a profile-one page of text and one page of illustrations-of each of nearly 150 historically significant sites beyond the Mississippi. Included for Iowa are Council Bluffs, Fort Madison, Davenport, and Mount Pisgah.

Mormon Settlement in Arizona, by James H. McClintock. Foreword by Charles S. Peterson. 1921. Reprint. Tucson: University of Arizona Press, 1985. xxi, 307 pp. Maps, illustrations, bibliography, appendixes (place names, chronology, tragedies), index. $\$ 9.95$ paper.

The North Reports the Civil War, by J. Cutler Andrews. 1955. Reprint. Pittsburgh: University of Pittsburgh Press, 1985 . xiii, 813 pp. Maps, notes, appendix, bibliography, index. $\$ 19.95$ paper.

Old Home Town, by Rose Wilder Lane. 1935, 1963. Reprint. Lincoln: Bison Book, University of Nebraska Press, 1985.309 pp. $\$ 8.50$.

Witnesses to a Vanishing America: The Nineteenth-Century Response, by Lee Clark Mitchell. Princeton: Princeton University Press, 1981. xvii, 320 pp. Notes, illustrations, bibliography, index. $\$ 26.50$ cloth; $\$ 14.95$ paper.

Working for the Railroad: The Organization of Work in the Nineteenth Century, by Walter Licht. Princeton: Princeton University Press, 1983. xx, 328 pp. Tables, illustrations, notes, appendixes, bibliography, index. $\$ 29.00$ cloth; $\$ 14.50$ paper. 
Copyright of Annals of Iowa is the property of State of Iowa, by \& through the State Historical Society of Iowa and its content may not be copied or emailed to multiple sites or posted to a listserv without the copyright holder's express written permission. However, users may print, download, or email articles for individual use. 